\title{
Sean Mills \\ The Empire Within: Postcolonial Thought and Political Activism in Sixties Montreal
}

Montreal and Kingston: McGill-Queen's University Press, 2010. ix, 303 pp.

\section{C.A. Watt}

St. Thomas University

In the back-cover marketing spin for this book, McGill-Queen's University Press declares that it is "a brilliant history of a turbulent time and place." Publishers should avoid making such rash and vexatious statements, as hyperbole can simultaneously raise readers' expectations and put them off.

Notwithstanding these initial frustrations I did enjoy Empire Within. It is a very good book with strong arguments and information aplenty. It is well-presented and author Sean Mills writes with élan and captures the excitement of Montréal and Québec in the late 1960s and early 1970s. The book's eight chapters (between 20 and 25 pages a piece) are well structured and manage to combine an analytical approach with an overall chronological narrative that builds to a climax in the strikes or, as Mills argues, "uprising" of May 1972 (202). Moreover, a wide variety of sources in French and English is well-documented in the abundant endnotes section and the bibliography. The book contains seven plates of useful and nicely-annotated photographs after page 84 , but unfortunately no maps are provided. Mills gives a good geographic description of Montréal c. 1960, but if the book is reprinted, maps of Montréal and the province of Québec must be added. The index could use improvement too. It is a mere five pages and omits many key terms and concepts such as "colonialism," "empire," "imperialism" (with subsections for British, French, American and Québecois imperialism), "decolonization theory," "education," "Marxism-Leninism," "New Left," "Third World," and "postcolonialism." What is more, entries for organizations like the "Confédération des syndicats nationaux" should be followed immediately by the acronym used in the text (CSN) — and as listed on the abbreviations page.

The main objective of Empire Within is to break analytical or heuristic boundaries and situate the ideas and practices of Montréal's political radicalism c. 1963-73 in 
broader local, continental, hemispheric and global contexts. The book is successful in showing how radical ideas could cross linguistic, ethnic and class boundaries to encourage imperfect and tenuous alliances between different groups and organizations. Gender boundaries were more problematic. Mills' analysis of Opération McGill français in March 1969 (chapter six) demonstrates how the interests of anglophone radical Jewish students and former faculty member Stanley Gray at McGill could overlap with those of francophone nationalists such as Raymond Lemieux and Québec labour organizations to lead to massive protests with more than 10,000 activists in the street. Issues regarding language and class were tied together by concerns about British or American colonialism and imperialism. In other words, McGill was seen as a colonial institution that benefitted anglophone capitalist élites while ignoring the interests of the majority of Montréal's and Québec's "colonized" francophone and working-class citizens.

Similarly, the 1969 riot at Sir George Williams University (SGWU) is reinterpreted by Mills in chapter four ("Montreal's Black Renaissance") and put in broader context to convincingly show its wider relevance to Montréal's radical politics. The language of Black activists borrowed from global anti-colonial struggles in West Africa and Cuba as well as Black radicals in the United States, but activist Alfie Roberts was also influenced by local francophone concerns about colonialism as embodied in Marcel Chaput's Pourquoi je suis séparatiste (106). Moreover, many francophone labour and student activists in Montréal stood in solidarity with Black activists as "nègres blancs d'Amérique" in the aftermath of the SGWU affair. This was one of those fragile alliances in which radical activists shared a common sense of exploitation and oppression by Anglo-American capitalism and colonialism.

The book succeeds admirably in showing the links between seemingly separate organizations or movements in Montréal and Québec (for discussions of the city occasionally morph into discussions of the entire province), as animated by a "language of decolonization" or "anti-colonialism." By the time readers get to chapters seven and eight about the October Crisis of 1970 and the mass, province-wide strikes of 1972, respectively, they will sense the febrile excitement of Montréal in the late 1960s and early 1970s. Thus the extent of the interaction and common anti-colonial ideological formations among different groups, organizations and movements that Mills outlines in previous chapters helps to support his argument that the strikes of 1972 constituted an "uprising" that vastly eclipses the FLQ and the October Crisis in terms of historical importance.

Mills is much less persuasive in his assertion that the intellectual ferment of Montréal c. 1970 constituted "postcolonial thought." In fact, this is a curious aspect of the book because while the phrase "postcolonial thought" is used in the book's subtitle ("Postcolonial Thought and Political Activism in Sixties Montreal"), it is only employed once or twice in the book itself. More importantly, the concept is not defined, explored or developed despite some awkward references on page eleven. Rather, the book's emphasis is consistently on how activists deployed a language of anti-colonialism, anti-imperialism and decolonization against real or perceived colonial oppressors (4-15 and passim). Mills could make the argument that by borrowing 
from the work of Albert Memmi, Aimé Césaire and Frantz Fanon radical activists in Montréal during the late 1960s were part of the vanguard of postcolonial thought, but he does not do so.

Lastly, the book contains much discussion of education at elementary, CEGEP and university levels, and the Québec teachers' union (Corporation des enseignants du Québec or CEQ) is presented as a progressive institution that supported various radical movements. There is also fascinating material about radical "community action" education initiatives undertaken by "social animators" and student collectives in factories, cafés and bookshops. These were often connected to leftist public history campaigns started by the Congress of Black Writers (chapter four) and the Montréal Central Council of the CSN (chapter 7). Unfortunately, Mills missed a golden opportunity to argue that these campaigns constituted "counter-hegemonic memory" and the "reappropriation of history," which are important aspects of postcolonial theory and activism.

Overall, Empire Within is a stimulating book that challenges many historiographical assumptions, but "postcolonial thought" does not belong in the title. 